\title{
OS PROGRAMAS NARRATIVOS DE “A CARNE DO METRÔ", CONTO DE RODRIGO LOPES DE BARROS: DO MAIS MENOS AO MAIS MAIS
}

\section{THE NARRATIVE PROGRAMS OF THE SHORT STORY “A CARNE DO METRÔ", BY RODRIGO LOPES DE BARROS: FROM MORE LESS TO MORE MORE}

\author{
Milton FRANCISCO ${ }^{1}$ \\ UFAC - Universidade Federal do Acre
}

RESUMO: Neste artigo, utilizando a teoria semiótica, fazemos uma leitura do conto "A carne do metrô", de Rodrigo Lopes de Barros, jovem contista brasileiro. Exploramos especialmente os conceitos de percurso e programa narrativos, actantes, junção, competências modais do sujeito. Também, fazemos uma breve leitura do conto à luz da semiótica tensiva e tecemos considerações sobre o sentido submerso, tratando-o como ironia.

PALAVRAS-CHAVE: Percurso narrativo; Programa narrativo; Actantes; Ironia; Conto; Rodrigo Lopes de Barros.

ABSTRACT: In this paper, using semiotic theory, we do a reading of the short story "A carne do metrô", by Rodrigo Lopes de Barros, a young Brazilian writer. We employed especially the concepts of narrative path, narrative program, actants, junction, modal competences of the subject. Furthermore, we made a brief reading of the short story in the light of tensive semiotics and we made considerations about the submerged meaning, treating it as irony.

KEYWORDS: Narrative path; Narrative program; Actants; Irony; Short story; Rodrigo Lopes de Barros.

As pessoas, então, espremeram-se mais, mais. [...] Uma faxineira observou o problema e resolveu cumprir com o seu dever.

O conto "A carne do metrô", de Rodrigo Lopes de Barros, é um dos textos vencedores do Concurso Nacional de Contos realizado em 2004 pelo jornal O Estado de S. Paulo em comemoração aos 450 anos da capital paulista. Inicialmente publicado em encarte especial da edição de 24 de fevereiro de 2004 do mesmo jornal, o conto é parte do livro homônimo publicado pela editora Katarina Kartonera em 2009.

Neste artigo, faremos uma leitura do conto a partir da teoria da semiótica (GREIMAS \& COURTÉS, 2012). Nossa análise percorre, especialmente, os conceitos de

\footnotetext{
${ }^{1}$ Professor da Universidade Federal do Acre. Doutorando na Universidade de São Paulo. Bolsista da Capes / Prodoutoral. Este artigo foi apresentado ao final da disciplina Semiótica: teoria e aplicação na canção brasileira ministrada em 2012 pelo professor Dr. Luiz Augusto de Moraes Tatit, a quem agradeço pela leitura e apontamentos, que muito contribuíram para sua publicação. Os equívocos que insistem em permanecer são todos meus.
} 
percurso narrativo, programa narrativo, actantes (sujeito, antissujeito e objeto), junção (conjunção e disjunção), competências modais do sujeito. Expomos os programas narrativos identificados no texto, apontando as relações hipotáxicas e de pressuposição entre eles. Desse modo, nos propomos a examinar o percurso narrativo, atentando especialmente para os actantes presentes, suas relações tensivas e as ações que estabelecem entre si.

Faremos, também, uma breve leitura do conto à luz da semiótica tensiva. Por fim, faremos observações sobre o sentido submerso que nos revela a ironia contida na superfície de "A carne do metrô".

$\mathrm{O}$ conto segue reproduzido em anexo.

\section{Percurso narrativo: a dinâmica dos actantes}

Em termos semióticos, uma narrativa pode ser entendida como programa(s) narrativo(s) vinculado(s) a um percurso narrativo. Termo amplo e hiperonímico, percurso narrativo é entendido, conforme Greimas \& Courtés (2012, p. 334), como "uma sequência hipotáxica de programas narrativos (abreviados em PN), simples ou complexos, isto é, um encadeamento lógico em que cada PN é pressuposto por outro PN".

Os PNs, unidades sintáticas simples, são compostos por actantes (sujeito, antissujeito e objeto). O sujeito - que pode ser de fazer ou de estado -, na formação do PN, quase sempre se depara com um antissujeito. Desse modo, toda narrativa pressupõe a existência de um sujeito (em busca de um objeto) e de um antissujeito. Esse agindo em direção daquele, de modo a provocar-lhe a falta ou o excesso de algo relativo ao objeto. O conflito entre ambos é o processo que irá constituir o núcleo da narrativa.

Entendemos que o conto "A carne do metrô" pode ser lido em quatro PNs, os quais analisamos a seguir.

\subsection{PN1 - Dezembro. [...] A camisa encharcada molhava os companheiros de viagem.}

Aqui, o sujeito são os usuários do transporte público (mulheres, crianças, homens, entre eles "um homem gordo"), os quais, na sua maioria, voltam para casa após um dia de trabalho, cansados e exaustos. Tais condições estabelecem como objeto desejado e buscado por essas pessoas a chegada em casa, o descanso e o conforto do lar.

Apesar das dificuldades no interior dos vagões, percebemos, especialmente pelo enunciado "Abaixo do asfalto, milhares de trabalhadores exaustos buscavam o metrô que os levaria ao lar" (enunciado de fazer), que o sujeito "caminha" em direção do objeto. Há aí relativa aproximação, o que assim se traduz no quadrado semiótico (GREIMAS \& COURTÉS, 2012, p. 279, p. 400-404):

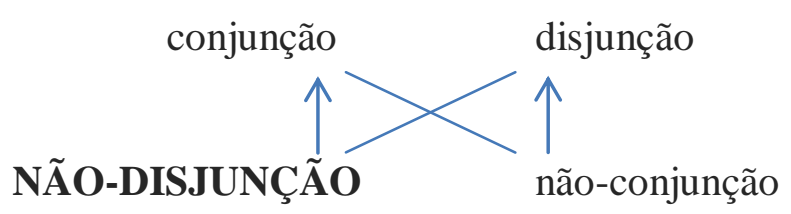

Figura 1

O enunciado de fazer expressa a passagem de um estado a outro. Isso significa que o sujeito, fortalecido, está em passagem do estado de não-disjunção para o de conjunção com o objeto, está a caminho da conjunção. 
No entanto, no deslocamento para casa, surge o antissujeito. Uma porção da sociedade - que poderíamos denominar "antissujeito externo" - exerce a função de dificultar a busca do objeto desejado e de direito dos trabalhadores no fim de tarde. Trata-se de um antissujeito de caráter social: é a falta de espaço ("Não havia espaço para todos"), o calor e o desconforto dentro dos vagões, a condição subumana do transporte público, as forças econômicas sobre o ser humano. Juntos, esses elementos componentes do antissujeito parecem estar, discursivamente, catalisados na figura do "homem gordo", mas sem que ele aja como antissujeito, pois nele não há intenção, iniciativa ou atuação de antissujeito. Sua função de "estorvo" (ocorrida de forma involuntária e passiva) caracteriza-se como antiobjeto. Não é possível nem mesmo dizer que o "homem gordo" seja um "actante dúbio", pois sua contribuição para o desconforto dos demais passageiros é involuntária. A propósito, ele e os demais "trabalhadores" querem/desejam o mesmo objeto: o descanso em casa.

Dentro do vagão em que está o "homem gordo", ocorre, portanto, um confronto entre o sujeito e o antissujeito, estabelecendo, assim, a não-conjunção entre sujeito e objeto. $O$ "antissujeito externo e social" está forte, vigoroso. No quadrado semiótico esse estado fica assim representado:

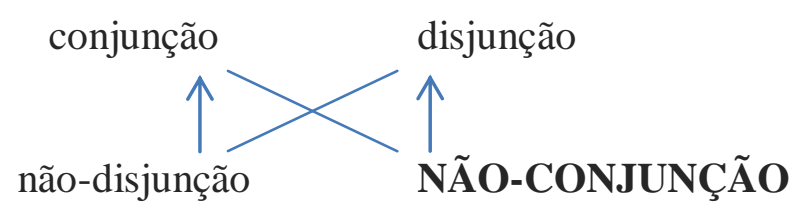

Figura 2

No nível discursivo, há indícios de que o "homem gordo" impede os demais passageiros de alcançarem o objeto, figurativizando as pessoas gordas como estorvos na nossa sociedade. Já no nível narrativo, o "homem gordo" é sujeito, que também deseja chegar a sua casa. Nesse sentido, a gordura do próprio corpo, juntamente com o calor e a falta de espaço, o incomoda, tal como incomoda os demais passageiros (a diferença está na perspectiva).

Devido a essa espécie de catalisação de diferentes forças actanciais, o "homem gordo" é um actante complexo, o que, de certo modo, constitui o núcleo da narrativa.

\subsection{PN2 - Começou a sentir-se tonto, [...] incômodo que seu peso ocasionou.}

Como continuação do PN1, o PN2 se centra no "homem gordo", actante que, sob a força do "antissujeito externo" (o calor, a falta de espaço e o desconforto dentro do vagão), não consegue alcançar o objeto desejado: a chegada em casa, o descanso e o conforto do lar. $\mathrm{Na}$ verdade, o sujeito tem interrompido o seu trajeto em direção à sua casa, a ponto de o "antissujeito externo" levá-lo à morte. A morte lhe é antiobjeto. Noutras palavras, há total disjunção do "homem gordo" com o objeto que ele buscava.

"O homem gordo, sobre as listras, que marcavam a zona de embarque", passa da vida à morte. Simbolicamente, "sobre as listras", ele cruza a linha da vida, em direção à nãoexistência. Como confirmação de que essa direção se cumpriu - não por vontade própria, e sim pela ação do "antissujeito externo e de cunho social" -, o narrador/enunciador declara: "Esse foi o último incômodo que seu peso ocasionou", à sociedade, evidentemente. É perceptível que a ênfase está no peso, na gordura, no corpo antissocial e dessocializado.

Vale notar que os usuários do metrô não se comportam como actante provocador da morte do "homem gordo", porque eles não estão, predominantemente, em relação de conflito 
com o "homem gordo". Tanto no PN1 quanto no PN2, o conflito - social - é do ser humano (inclusive o "homem gordo") com o "antissujeito externo".

No PN2, exceto com relação ao "homem gordo", pressupõe-se que, apesar da força do antissujeito, as pessoas cheguem às suas casas, alcançando o objeto e tendo seu desejo satisfeito. Subentende-se, portanto, a ocorrência da conjunção do sujeito (exceto o "homem gordo") com o objeto. É como se o sujeito ("milhares de trabalhadores exaustos" usuários do metrô), em razão do seu direito de voltar para casa - o que lhe dá força nesse confronto -, rompesse contra o antissujeito. Isso ocorre porque "o sujeito faz o que faz com o fito de entrar em conjunção com o seu objeto” (LOPES, 1989/1990, p. 155).

No âmbito do PN2, observamos ainda um subprograma, no seguinte enunciado: "Os passageiros, aflitos com a situação, decidiram ajudar. Na primeira parada, arremessaram o gordo para fora do vagão. Tarefa difícil, oito pessoas. Abandonaram-no rapidamente". Com essa ação, os passageiros se livram do problema que um dos seus "companheiros de viagem" se tornara.

O "homem gordo", de sujeito no PN1, e, num certo momento, com a função involuntária e passiva de "estorvo" (o que lhe dá aspecto de antiobjeto dos demais passageiros), passa a ser, devido à força excessiva do "antissujeito externo", objeto no final do PN2. Aquele "homem gordo" agora é "uma massa inerte", um "corpo rígido", sem poder agir, desprovido de qualquer querer.

\subsection{PN3 - Uma faxineira observou o problema [...] a saliva espumando em seus lábios.}

Diante do "homem gordo" transformado por parte da sociedade em objeto, surge agora uma faxineira originando novo PN: "Uma faxineira observou o problema" [que não é propriamente um problema, pois "o último incômodo" ocorre no final do PN2; só ironia do narrador] "e resolveu cumprir com o seu dever". Ou seja, especificamente, ele se torna objeto da faxineira, representante da limpeza social. E, abrindo as objetivas, percebemos: ele é transformado por parte da sociedade (o "antissujeito externo") em objeto dessa mesma sociedade.

O encontro do sujeito (a faxineira) com o objeto se realiza na busca de sujeira e exercício de limpeza do chão do metrô. Isto é, o sujeito não está, de forma consciente, em busca nem à espera desse objeto ("o corpo"), nem mesmo aparentemente. O encontro é um acontecimento inesperado, ocorre como surpresa, como sobrevir (isso em termos relativos). Também relativamente, há impacto, há tonicidade, há pontualidade, é sem difusão, na linguagem semiótica.

Sob o domínio da faxineira, "o corpo do gordo" é conduzido por ela "para baixo das escadas" (ação com a qual ela se comporta como espécie de sujeito/personagem direcionador do percurso narrativo). Essa ação é uma preparação do que virá: o acontecimento nuclear do PN4, como será demonstrado a seguir.

Nesse encontro e ação da faxineira, ocorre conjunção do sujeito com o objeto, sem interferência ou presença de qualquer antissujeito. O corpo é festejado com euforia pela faxineira: "Graças ao meu bom Deus te encontrei - disse com a saliva espumando em seus lábios". Esses aspectos podem ser assim representados no quadrado semiótico:

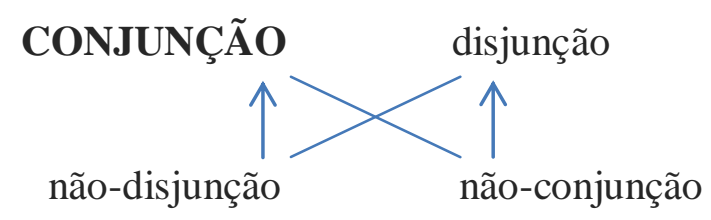

Disponível em: http://seer.fclar.unesp.br/casa 


\section{Figura 3}

Embora ocorra conjunção, ela não é plena e nem conclusiva. Além disso, a vida não para. A narrativa do PN3 é apenas uma preparação para o PN4, onde se dá o ápice de "A carne do metrô".

\subsection{PN4 - O morto adiposo descansou [...] numa fogueira improvisada.}

No enunciado "O morto adiposo descansou tranquilamente em seu esconderijo", o tempo é relativamente longo e lento, e nada acontece. Ao mesmo tempo, a força em relação a qualquer acontecimento é extremamente tênue (sentido expresso sobretudo por "descansou tranquilamente"). Quanto ao espaço, há forte restrição e fechamento, que é um sentido contido sobretudo em "esconderijo".

O mesmo enunciado revela que o "morto adiposo" - inicialmente um actante cheio de vitalidade que provoca impacto nos demais passageiros na estação do metrô e dentro do vagão, e tonifica a aproximação física entre eles nesses espaços, não tão fechados quanto ao "esconderijo" em que agora descansa - finda enfraquecido, atonizado, apagado. Desse modo, o foco é sobre o repouso do morto, como se, "em seu esconderijo", já seguisse em direção à eternidade, o que contribui para o sentido da narrativa (pois deixa de ocupar determinado espaço no metrô, na sociedade, no mundo).

Apesar disso, a forma verbal "descansou" marca essa situação como algo passado e, ao mesmo tempo, aponta para um futuro próximo, para o que viria a ocorrer com o "morto adiposo". Essa forma verbal como tal é relevante para que esse enunciado participe do PN4, e não do PN3, como talvez possa parecer devido à relação existente entre "para baixo das escadas" (PN3) e "seu esconderijo" (PN4).

O corpo do "homem gordo" (objeto), repousado sob as escadas, fica "esquecido" até o momento "quando o metrô completa sua jornada", até o fim do expediente dos faxineiros. Trata-se, sobretudo, do momento de "a mulher e todos os outros faxineiros" ("sujeito coletivo") encontrarem, de fato, o objeto, os quais o festejarão com euforia.

Nas entrelinhas, a narrativa revela que tal encontro foi mentalmente planejado e esperado pela faxineira. Assim, após levar o corpo "para baixo das escadas" (PN3), ela segue fazendo a faxina do metrô, espacial e relativamente distante do objeto. Distancia-se do objeto mantendo-o forte na memória, o que se caracteriza como potencialização, cuja representação é, na semiótica, $\mathbf{S}$ não-ก $\mathbf{O}$, isto é, a não-realização da conjunção do sujeito com o objeto. Nesse passar de tempo, a faxineira se mantém à espera do momento de reencontrá-lo: de mostrar e compartilhar com os companheiros de trabalho o objeto conquistado: "o morto adiposo".

Nesse encontro, há conjunção plena (plenitude conjuntiva) do sujeito ("a mulher e todos os outros faxineiros") com o objeto ("o morto"), e gozo dessa conjunção. Tal plenitude é expressa, por exemplo, em "Parabéns, minha princesa!", e em "riram bastante", e "assaramna numa fogueira improvisada". Aqui, ao final do conto, ocorre o que a semiótica denomina realização: isto é, o sujeito em conjunção com o objeto atinge a plenitude, cuja representação é $\mathbf{S} \cap \mathbf{O}$.

Se quisermos pensar esse momento em termos do quadrado semiótico, podemos repetir aqui a figura 3.

Além da conjunção do "sujeito coletivo" com o objeto, há forte consenso e harmonia entre os personagens componentes do sujeito: "Reuniram-se, depois, em círculo". A reunião de pessoas em forma de círculo é, por figurativização, a imagem de compartilhamento do que 
dentro dele circula. O que é consumido ou verbalizado dentro do círculo "advém" da convergência dos membros que o compõem, sem qualquer pertencimento, em última análise, ao mundo exterior. Essa harmonia e convergência estão expressas, também, em "Todos, então, retiraram as facas [...] começaram a retalhar-lhe a imensa quantidade de gordura amarelecida", o que ocorre como ação conjunta e compartilhada.

No eixo da intensividade, o andamento do tempo é lento (o encontro prolonga-se após o trabalho, durante a madrugada); quanto à tonicidade, o conteúdo sensível é tônico ("assustavam-se $\log$ o com a imensidão do corpo, começaram a retalhar-lhe, Espetaram a carne"); há forte tenuidade ("Não foi nada, riram bastante", há descanso e relaxamento). Já no eixo da extensividade, no ponto de vista da temporalidade, há dilatação/alongamento do tempo (após o trabalho, durante a madrugada); quanto à espacialidade, há fechamento do espaço ("sob as escadas, em círculo"); simultaneamente, há concentração/triagem.

Como síntese do percurso narrativo (a sequência de PNs), segundo esta análise, a morte do "homem gordo" tem papel tão forte na narrativa a ponto de provocar mudança da direção do percurso narrativo. $\mathrm{O}$ objeto desejado e buscado inicialmente pelos passageiros fica nas entrelinhas do PN2 e, ao mesmo tempo, é tirado de cena.

\section{O fazer e as competências modais do sujeito}

No âmbito da sintaxe narrativa de superfície, podemos identificar nesses PNs (que se relacionam hierarquicamente) as diferentes ações dos actantes em relação ao fazer, verbo cujo sentido/valor é crucial na teoria semiótica.

Acompanhando o verbo fazer aparecem o querer, o poder, o dever e o saber, os quais assumem valores modais e modalizam o fazer. Juntos, dizem muito sobre os actantes da narrativa, sobretudo o sujeito, que é o actante do querer-fazer, do poder-fazer, do deverfazer (estrutura modal denominada prescrição, conforme Greimas \& Courtés, 2012, p. 315) e do saber-fazer.

Especialmente sobre os verbos querer e fazer, Lopes (1989/1990, p. 156) considera que há entre eles uma linha de complementaridade dinâmica, enquanto entre o sujeito (aquele que quer) e o objeto (o que é querido) há uma complementaridade estática. De acordo com Lopes (1989/1990, p. 156),

querer e fazer entram em linha de complementaridade dinâmica porque se situam como uma mesma entidade dotada de diferentes modos de existência, vistas em distintas fases do percurso narrativo como a potência e o ato:

- o querer é o fazer interior que atualiza um ato em potência;

- em relação a esse querer, o fazer constitui a prática exterior que realiza a potência (do querer) em ato.

Ao atentarmos para o uso desses verbos, fazemos remissão à performance do sujeito. Considerando essa performance de forma ampla, tais ações verbais, ou o desejo de executá-las, podem ser vistas na perspectiva da pragmática - campo de estudo da linguagem do qual a semiótica toma alguns conceitos. Assim, tais ações podem ser executadas implícita ou explicitamente na dimensão pragmática (tem-se o fazer pragmático), como também serem apenas desejadas na dimensão cognitiva (tem-se o fazer cognitivo). Sobre a distinção fazer pragmático e fazer cognitivo, Greimas \& Courtés (2012, p. 202) advertem: "Essa oposição, que se impõe primeiro como uma evidência, não é, entretanto, de natureza sintática e não se impõe a não ser em níveis de linguagem mais superficiais".

Disponível em: http://seer.fclar.unesp.br/casa 
Tal como os PNs, os "fazeres" se relacionam hierarquicamente, como será demonstrado a seguir.

Como já sabemos, o conto "A carne do metrô" constitui-se em um programa narrativo complexo por integrar vários PNs. Os programas narrativos complexos

são chamados de PN de base, são complexificados pelo reconhecimento dos enunciados modais que regem os enunciados de fazer. Tendo-se de considerar o programa narrativo, enquanto 'fazer-ser' do sujeito, como a performance deste, as modalidades - tais como a do querer-fazer ou a do poder-fazer surgem como condições necessárias à realização dessa performance e constituem assim o que se poderia designar competência modal do sujeito. (GREIMAS \& COURTÉS, 2012, p. 476).

No PN1, os usuários do transporte público, "milhares de trabalhadores exaustos", inclusive o "homem gordo", querem ir para casa (é o querer-fazer), pois não podem ficar no trabalho nem na rua, isto é, devem ir para casa (é o dever-fazer), independentemente das ações do "antissujeito externo". Aqui, o dever-fazer pressupõe e é imanente ao querer-fazer.

No PN2, os usuários do metrô, exceto o "homem gordo", concretizam o dever-fazer (embora não explicitado pelo narrador), realizam o fazer pragmático (ainda que não no âmbito da narratividade de "A carne do metrô"), apesar das ações contrárias do "antissujeito externo".

Ainda no PN2, o "homem gordo" também quer e deve ir para casa (é o querer-fazer e o dever-fazer), mas, por causa das ações do "antissujeito externo", sente-se impotente e não pode fazê-lo (é o não poder-fazer), a ponto de o antissujeito torná-lo objeto para a faxineira. Aqui, o não poder-fazer sobressalta e anula o querer-fazer. $O$ seu querer-fazer e seu dever-fazer limitam-se ao fazer cognitivo.

No PN3, a faxineira deve limpar o metrô (é o dever-fazer) e o faz (é o poder-fazer) num misto de obrigação e de liberdade. Ou seja, realiza sua função de faxineira, inclusive "limpando" o "corpo do gordo" do caminho dos usuários do metrô. Aqui, tanto o dever-fazer quanto o poder-fazer pressupõem um saber-fazer. Mas, ao mesmo tempo em que faz o que deve fazer, ela faz o que deseja fazer (é o querer-fazer), isto é, leva o "corpo do gordo para baixo das escadas", mantendo-o escondido até o fim do expediente (é o saber-fazer). Aqui, o querer-fazer pressupõe o saber-fazer; por outro lado, o saber-fazer permite o querer-fazer. A faxineira executa o fazer pragmático.

No PN4, "a mulher e todos os outros faxineiros" desejam (ainda que não no âmbito da narratividade) comer carne humana (é o querer-fazer) e o fazem - em decorrência da ação de esconder "o corpo do gordo" realizada anteriormente pela faxineira - "quando o metrô completa sua jornada" (é o poder-fazer). Aqui, o poder-fazer soma-se ao querer-fazer. Mas, de forma subjacente e mais forte, existe a ação de um dever-fazer, que advém do fato de haver sob as escadas um corpo a ser consumido naquela noite, sem qualquer postergação. Nesse caso, o fazer pragmático tornara-se obrigação.

\section{0 actante gordo e seus papéis actanciais}

O percurso narrativo trilhado pelo actante "homem gordo"- caracterizado pela mudança de papéis actanciais: ora ser sujeito; ora exercer passivamente a função de "estorvo" e parecer contribuir com o antissujeito (em relação aos demais passageiros); ora ser objeto remete às múltiplas relações sociais que homens e mulheres estabelecem entre si na sociedade contemporânea cotidianamente. 
Na perspectiva da figurativização (GREIMAS \& COURTÉS, 2012), o percurso narrativo realizado por esse actante é o percurso que muitas pessoas gordas realizam, sob forças sociais diversas, na sociedade ocidental contemporânea. Sua gordura incomoda e pressiona física e psicologicamente a si próprias e às pessoas com quem dividem os espaços público-coletivos.

Devido a tais forças (as quais são mais bem entendidas como forças ideológicas), as pessoas gordas, apesar de (e devido a) seu maior peso e maior volume do que o das demais pessoas, são "derrotadas", subjugadas, desvalorizadas, inferiorizadas, estigmatizadas, tornando-se indivíduos sem vida social deslocados para fora da sociedade, que se recolhem em casa e se consomem depressivamente. Ou, na melhor das hipóteses, também devido a tais forças, submetem-se a um processo anti-humano de dietas, de medicamentos e de cirurgias, a fim de extinguirem a própria gordura e, assim, se manterem ativas na sociedade.

Tanto um caso quanto o outro - "depressão" ou "dietas" e "cirurgias": ponto extremo da vida social - aparecem no conto, por figurativização, com o "gordo objeto" consumido "nas pontas afiadas das vassouras" dos faxineiros, representantes do "canibalismo social" e da "limpeza" que se tenta fazer (e que aos poucos cotidianamente se concretiza) da forma do corpo humano indesejada na sociedade. No entanto, no conto ocorre um canibalismo às avessas. Enquanto no conto o indivíduo que se alimenta do outro quer se nutrir das substâncias do outro, na sociedade o indivíduo quer vê-lo ausente, assim como ver suas (ou as próprias) características físicas e psicológicas socialmente extintas.

Nesse sentido, a narratividade de "A carne do metrô" é um recorte figurativo (no plano do conteúdo) da vida social, forjada por valores determinados por uma estética de consumo e de princípios morais definidos por forças coercivas de dominação, forjada pelo desejo de poder do mercado econômico que divide as pessoas em fracassados e vitoriosos.

\section{0 mais e o menos: aproximações e distanciamentos}

Na perspectiva semiótica, o que desencadeia a narratividade é a ação do antissujeito sobre o sujeito, provocando a falta ou o excesso de algo da esfera do sujeito ou da esfera do objeto buscado pelo sujeito. Sem essa ação, não há mudança de estado no mundo do sujeito nem ele se move em busca de algo para suprir qualquer carência. Ao agir, o antissujeito provoca alteração gradativa (em maior ou menor grau) em um ou mais elementos do mundo do sujeito, por exemplo, em relação ao acesso ao objeto, em relação aos sentimentos emotivos do sujeito (ou das personagens da narrativa). Ao mesmo tempo, o sujeito, para não se findar, de alguma maneira entra em "confronto de defesa" com o antissujeito. Essas modificações discursivas, em semiótica tensiva, podem ser quantificadas em [mais menos], [menos menos], [menos mais] e [mais mais] (ZILBERBERG, 2006).

Quando a força é [mais menos], a direção é descendente, é para a incompletude e a escassez ou falta de algo, sobretudo do mundo do sujeito. Aqui, o antissujeito é o actante forte. Nesse caso, a situação impõe ao sujeito a liquidação dessa falta, isto é, a parada da parada, de modo a mudar o rumo da situação, tornando-a ascendente. Numa situação ascendente, o sujeito é o actante forte.

Quando a força é [mais mais], a direção é ascendente, é para a extravagância e o excesso de algo, sobretudo do mundo do sujeito. Aqui, o sujeito é o actante forte. Nesse caso, a situação impõe ao sujeito a fixação de limites, isto é, a parada da continuação, de modo a mudar o rumo da situação, tornando-a descendente. Numa situação descendente, o antissujeito é o actante forte.

A seguir, serão aplicados tais critérios de quantificação nos PNs vistos anteriormente. 


\subsection{PN1}

No começo do conto a descrição físico-sensorial do ambiente se dá na aura do [mais menos] e já revela a presença da força do antissujeito: "as cinzentas avenidas de São Paulo" tornavam-se ainda mais sombreadas pelo crepúsculo que se abatia, isto é, tornavam-se [mais menos claras].

Num espaço mais restrito [mais menos amplo] do que as avenidas, "abaixo do asfalto, milhares de trabalhadores exaustos" [mais menos dispostos] "buscavam o metrô que os levaria ao lar". "Não havia espaço para todos" [mais menos espaço]. "Dentro dos vagões os indivíduos apertavam-se" [cada vez mais menos espaço]. O espaço parecia ficar cada vez menor, à medida que as pessoas apertavam-se cada vez mais. Noutras palavras, há escassez/falta de espaço para o sujeito. É o "antissujeito externo e social" em ação contra o sujeito. Nessa situação, o sujeito ("milhares de trabalhadores") quer/deseja que isso não continue e que haja uma parada da continuação, quer o enfraquecimento do antissujeito.

No entanto, a situação ganha [mais menos] com a fortificação do "antissujeito externo e social": "Descendo as escadas congestionadas" [mais menos espaço], "surgia um homem gordo" (sujeito que também sofre as ações do antissujeito) "que esbarrava seu gigantesco corpo nas mulheres e crianças. Mal passou pelas catracas" [mais menos]. "Com muito esforço, tomou o trem para o Tietê. A barriga imensa ocupava" [mais menos espaço para os demais passageiros] "folgadamente o lugar de mais três. Comprimido" [mais menos espaço] "era pelos outros passageiros, que o encaravam com ódio. O calor crescia" [mais menos confortável] "tornando-se insuportável" [cada vez mais menos confortável]. "Bagas de suor azedo" [mais menos agradável] "brotavam da tez pálida do gordo. A camisa encharcada molhava" [mais menos agradável] "os companheiros de viagem". O actante forte nesse momento é o "antissujeito externo e social", a ponto de provocar, em termos semióticos, saturação.

Haveria de explodir a qualquer momento essa situação que, sem limites aparentes, crescia em desconforto para todos os passageiros - entre eles o "homem gordo"- dentro daquele vagão. Cada vez [mais menos conforto]. Nada suporta tanta escassez, incompletude e falta. Tudo que se propõe a progredir desse modo encontra, num certo momento, a parada da continuação (o que ocorre no final do PN2), e, em seguida, muito provavelmente, entra em queda, isto é, ganha em [menos menos] e, em seguida, em [mais mais]. Essa guinada de que falamos e que, na perspectiva da semiótica, é inevitável ocorre na passagem do PN2 para o PN3.

\subsection{PN2}

Neste PN, continuação do PN1, a falta e escassez de espaço é tão grande (isto é, o antissujeito é tão forte) a ponto de atingir um dos sujeitos: o "homem gordo", que no PN2 se torna enfaticamente sujeito-vítima do "antissujeito externo".

O excesso de menos atinge o "homem gordo": aparentemente forte, é derrotado pelo calor e pelo excesso de falta de espaço. O seu enfraquecimento é narrado na ordem do [mais menos]: "Começou a sentir-se tonto, indisposto" [mais menos disposto], "claustrófobo. A visão embaçou-se-lhe" [mais menos visão]. "Desmaiou. Mas não caiu. Não havia espaço" [mais menos espaço]. "Ficou sustentado pelo corpo dos outros passageiros. Ninguém percebeu" [mais menos percepção] "seus olhos cerrados" [mais menos visão], "até que o gordo passou a sofrer um ataque epilético" [mais menos vida]. "Tremia como um porco agônico" [intensifica-se o ataque epilético: mais menos vida]. "As pessoas, então, 
espremeram-se mais, mais" [mais menos espaço]. "Ele, pouco a pouco, desabou no chão metálico, debatendo-se" [mais menos vida]. "Os passageiros, aflitos" [mais menos tranquilidade] "com a situação, decidiram ajudar. Na primeira parada, arremessaram o gordo para fora do vagão". Essa é uma "ação final" que intensifica o enfraquecimento do "homem gordo". Continua o narrador: "Tarefa difícil" [mais menos facilidade], "oito pessoas. Abandonaram-no rapidamente" [mais menos tempo]. "Em seguida, sua tremedeira cessou" [cada vez mais menos vida] "e ele tornou-se uma massa inerte. Morrera" [mais menos, em excesso, falta de vida].

Com o excesso de menos, algo forte haveria de ocorrer. Ocorre a morte do "homem gordo", que não consegue reagir contra o antissujeito.

\subsection{PN3}

No PN3, o antissujeito é fraco e imperceptível. O sujeito ("a faxineira") se aproxima do seu objeto ("o corpo do gordo") e o conduz como bem entende, preparando-o para o PN seguinte. Aqui as relações e as forças são de [mais mais], embora seja de baixa intensidade, pois trata-se de aproximação, e não de excesso ou de total/plena conjunção: "Uma faxineira observou" [mais mais visão do objeto] "o problema e resolveu cumprir com o seu dever" [mais mais aproximação]. "Era uma mulher extraordinariamente musculosa" [mais mais poder sobre o objeto]. "Repousou a vassoura num pilar robusto e aproximou-se a passos sinuosos" [mais mais aproximação]. "Ergueu o corpo do gordo e levou-o em seus braços" [mais mais posse sobre o "corpo"]," de maneira ligeira, para baixo das escadas que davam acesso à estação. Ajeitou o cadáver cuidadosamente" [mais mais], "como se desejasse escondê-lo" [mais mais posse sobre o objeto]. "Ajoelhou-se comedida, cheirou o defunto e lambeu freneticamente" [mais mais exaltação/excitação interior] "o sangue morno" [mais mais frio, no nível do sujeito; menos mais quente, no nível do objeto] "que lhe escorria da orelha" [mais mais posse e aproximação sensorial].

"- Graças ao meu bom Deus te encontrei - disse com a saliva espumando em seus lábios" [mais mais aproximação cognitiva e sensorial].

Aqui, a faxineira parece querer cada vez mais se aproximar e se apoderar, inclusive fisicamente, do "corpo do gordo". Há relação de ascendência e o actante forte é o sujeito. Nesse momento, a sensação que permeia a narrativa é a de continuação da continuação. Mas, como já notamos, o PN3 é uma preparação para o PN4. A questão é sabermos se permanece a continuação da continuação ou se há parada da continuação.

\subsection{PN4}

No PN4 prevalece a força de [mais mais], isto é, o sujeito é forte e obtém maior aproximação com o objeto.

"O morto adiposo descansou tranquilamente" (isso na perspectiva do sujeito, pois "o morto adiposo" é um objeto inerte) "em seu esconderijo" [mais mais possuído pelo sujeito]. "À meia-noite, quando o metrô completa sua jornada, a mulher e todos os outros faxineiros reuniram-se sob as escadas, resplandecentes" [mais mais satisfação] "de um vazio inimaginável há algumas horas. Nessa noite, os cumprimentos entre eles foram esquecidos" [menos aproximação entre os faxineiros, isto é, menos mais (atenuação), devido a mais mais aproximação com o objeto], "pois os que chegavam assustavam-se" [mais mais contemplação] "logo com a imensidão" [mais mais alimento à vista] "do corpo que ali jazia". 
“- Vejam - disse um dos faxineiros, apontando a carcaça com uma mão e tapando a boca escancarada com a outra" [mais mais admiração e êxtase por terem o objeto]. - É muito grande [mais mais alimento]. "Parabéns, minha princesa" [mais mais contemplação]!

"- Não foi nada" [menos mais (atenuação), porém por falsa modéstia]. "Esse caiu do céu - observou a mulher, demonstrando modéstia".

"Todos, então, retiraram as facas que guardavam numa discreta bainha pendurada na cintura" [mais mais certeza de aproximação com o objeto]. "Despiram o morto, rasgando suas encardidas roupas" [mais mais aproximação], "e, logo em seguida, começaram a retalhar-lhe" [mais mais aproximação e acesso] "a imensa quantidade de gordura amarelecida. Reuniramse, depois, em círculo" [mais mais aproximação dos faxineiros entre si, e mais mais posse do objeto]. "Espetaram a carne nas pontas afiadas das vassouras, riram bastante" [mais mais prazer], "e assaram-na numa fogueira improvisada" [mais mais].

Sem nenhuma força de qualquer antissujeito, o PN4 progride sob as forças do actante sujeito. Assim, entram num processo de continuação da continuação (o que de certo modo responde à questão posta ao final da análise do PN anterior) aparentemente sem fim, de total conjunção do sujeito com o objeto. O sujeito atinge descontração e relaxamento total: por exemplo, "riram bastante".

Ocorre no PN4 recrudescimento [mais mais, aumento demais], que é o estágio elevado de restabelecimento [menos menos]. Ao final da narrativa, a sensação é de que ocorrerá saturação [só mais], o que seria, na perspectiva da semiótica, insuportável para os faxineiros, como para qualquer ser humano. A plenitude, satisfação e gozo do "banquete", obviamente, não se estende no tempo, pois os faxineiros, como seres humanos, não suportariam a intensidade do momento por longo período. Na verdade, sabemos, por mais que os faxineiros prolonguem o momento em volta da "fogueira improvisada", a carne e a madrugada terá fim. Ou seja, o objeto consumido e o tempo evitarão tal saturação, mas sem prejudicar a satisfação orgânica e moral dos faxineiros (sujeito coletivo).

\section{Sentido latente: a ironia}

Identificamos no PN4 o compartilhamento do "morto adiposo" pelos faxineiros como conjunção plena: uma ceia, um "banquete" de satisfação e gozo. Mas precisamos ir além, submergir, pois há nessa plenitude grande ironia que precisa ser descrita, pois diz respeito ao elemento principal da mensagem do texto. Referimo-nos ao sentido subentendido, submerso, latente, o qual a superfície do texto, omitindo, permite. Omite porque revela oposição. Permite porque necessita, porque é literatura.

Para tanto, o fato de o conto ambientar-se no metrô diz muito, pois, na sociedade contemporânea, o metrô é um dos símbolos do desenvolvimento econômico capitalista. Disso abstraímos que tal desenvolvimento é o propulsor dos sujeitos/actantes e dos eventos aí narrados.

Rumo ao sentido submerso, podemos perceber três importantes elementos na/da narrativa. Primeiro, a agressiva falta de espaço no metrô e dentro dos vagões simboliza a escassez de humanidade entre os cidadãos em geral, especialmente nas grandes cidades. Segundo, como entremeio está, ironicamente, "uma mulher extraordinariamente musculosa", cuja função de posse do "corpo do gordo" (a ela submisso) remete à posição social ocupada pela mulher nas últimas décadas. Terceiro, o ato de os faxineiros retalharem o "morto adiposo" ao final da noite descreve a tentativa de as pessoas em geral obterem mais espaço físico no ambiente público (nesse caso o metrô é emblemático: por ser subterrâneo, tem 
espaço diminuto). $\mathrm{O}$ ato de devorar canibalisticamente o outro é tomar-lhe o espaço no ambiente público, na cidade, no mundo.

Os três elementos estão intimamente integrados, a ponto de o terceiro ser consequência do primeiro, servindo o segundo como ponte crucial entre ambos. Na verdade, com o trabalho e a liderança de "uma mulher" obtém-se o que se deseja: espaço e alimento. Importante ressaltar: são três elementos desencadeados pelas forças socioeconômicas do capitalismo exacerbado da sociedade contemporânea a que todos nós (leitores e personagens urbanos) estamos submetidos, quer como "passageiro", quer como "homem gordo", quer como "faxineiro(a)".

Nesse contexto é que a satisfação e gozo ao final do conto se realizam no campo da ironia. Assim se realizam porque (e sobretudo) decorrem das condições subumanas e antihumanas - relativas ao trabalho e ao transporte público a ele vinculado - a que se submetem diariamente milhões de trabalhadores das grandes cidades do mundo.

Tal satisfação e gozo são ironia também porque, tal como os faxineiros retalham, assam e consomem um passageiro do metrô encontrado morto, o mesmo podem fazer com um dos seus pares numa noite "sem passageiro", por exemplo. Essa hipótese se torna forte diante da percepção (ainda que seja de menor interesse para a semiótica) de que os faxineiros rotineiramente assassinem usuários do metrô - não necessária ou preferencialmente homens gordos - para se alimentarem ao final da noite. Isso se mostra subjacente na fala da faxineira: "Não foi nada. Esse caiu do céu". Isto é, outros corpos noutras noites não "caíam/caem do céu". Tal informação é reiterada em seguida, também implicitamente: "Todos, então, retiraram as facas que guardavam numa discreta bainha pendurada na cintura". Faz parte da rotina dos faxineiros, portanto, comerem carne humana após o expediente: mantêm discretamente na cintura as facas e usam "as pontas afiadas das vassouras" - instrumento de uso rotineiro e obrigatório na faxina do metrô - para assarem a carne. (Talvez possamos indagar como, de praxe, os faxineiros conseguem outros corpos, a refeição, a ceia). A alegria, euforia, satisfação e gozo na noite do conto são especialmente indícios do que poderia ocorrer noutras noites, são indícios do avesso a que estão sujeitos cada um dos faxineiros.

Nesse rumo, o "banquete", "a carne nas pontas afiadas das vassouras", simboliza a miséria e degradação humana sob as forças econômicas da sociedade contemporânea capitalista. Enquanto o capital se impõe, os trabalhadores "riem bastante" com a (da) própria desgraça: ironia pura.

Se o desenvolvimento econômico capitalista dá forças e poder às pessoas (sujeitos da vida social), é no sentido de - a exemplo do que faz o ser humano ao longo da narrativa destruírem uns aos outros, autodestruírem-se, autodefinharem-se, quase sempre coletivamente: ora "passageiros", ora "faxineiros", em ação. É a coletividade se "devorando" e "devorando" o indivíduo nos seus mais diferentes aspectos: moral e fisicamente, material e espiritualmente, por exemplo.

Como resultado último desse desenvolvimento, a situação dos faxineiros é degradante. No metrô subterrâneo, a distância física entre o ser humano morto (cadáver, defunto) e o ser humano vivo é nenhuma. Circulando ou trabalhando no metrô subterrâneo, passageiros e faxineiros dividem um só espaço físico com os vermes que se alimentam de cadáveres. Nas ínfimas galerias subterrâneas, aproximam-se ética e moralmente dos vermes. Nesse sentido, ao se alimentarem do "morto adiposo", os faxineiros, produto-vítimas do desenvolvimento econômico capitalista, são os próprios vermes.

Aqui, toda euforia é só ironia, é disforia! A propósito, euforia é sensação de alegria intensa sem necessariamente corresponder ao estado de quem a expressa; em geral, é sensação provocada por substância exterior, aspecto que fortalece a ironia em "A carne do metrô". 


\section{REFERÊNCIAS}

GREIMAS, A. J. \& COURTÉS, J. Dicionário de semiótica. Trad. Alceu Dias Lima et al. 2 ed. São Paulo: Contexto, 2012.

LOPES, E. Paixões no espelho: sujeito e objeto como investimentos passionais primordiais. In: Cruzeiro Semiótico. Porto, Associação Portuguesa de Semiótica, n. 11 e 12, jul./1989 jan./1990, p. 154-160.

BARROS, R. L. de. A carne do metrô. In: A carne do metrô. Florianópolis: Katarina Kartonera, 2009, p. 5-7.

ZILBERBERG, C. Razão e poética do sentido. Trad. Ivã Carlos Lopes, Luiz Tatit e Waldir Beividas. São Paulo: Edusp, 2006.

\section{ANEXO}

\section{A carne do metrô}

Dezembro. Abatia-se o crepúsculo sombreando as cinzentas avenidas de São Paulo. Abaixo do asfalto, milhares de trabalhadores exaustos buscavam o metrô que os levaria ao lar. Não havia espaço para todos. Dentro dos vagões, os indivíduos apertavam-se, esfregando-se uns nos outros, somente não copulando graças ao jeans defensor. Descendo as escadas congestionadas, surgia um homem gordo que esbarrava seu gigantesco corpo nas mulheres e crianças. Mal passou pelas catracas. Com muito esforço, tomou o trem para o Tietê. A barriga imensa ocupava folgadamente o lugar de mais três. Comprimido era pelos outros passageiros, que o encaravam com ódio. O calor crescia tornando-se insuportável. Bagas de suor azedo brotavam da tez pálida do gordo. A camisa encharcada molhava os companheiros de viagem. Começou a sentir-se tonto, indisposto, claustrófobo. A visão embaçou-se-lhe. Desmaiou. Mas não caiu. Não havia espaço. Ficou sustentado pelo corpo dos outros passageiros. Ninguém percebeu seus olhos cerrados, até que o gordo passou a sofrer um ataque epilético. Tremia como um porco agônico. As pessoas, então, espremeram-se mais, mais. Ele, pouco a pouco, desabou no chão metálico, debatendo-se. Os passageiros, aflitos com a situação, decidiram ajudar. Na primeira parada, arremessaram o gordo para fora do vagão. Tarefa difícil, oito pessoas. Abandonaram-no rapidamente. Em seguida, sua tremedeira cessou e ele tornou-se uma massa inerte. Morrera. Com o corpo rígido sobre as listras, que marcavam a zona de embarque, atrapalhou o fluxo. Esse foi o último incômodo que seu peso ocasionou.

Uma faxineira observou o problema e resolveu cumprir com o seu dever. Era uma mulher extraordinariamente musculosa. Repousou a vassoura num pilar robusto e aproximouse a passos sinuosos. Ergueu o corpo do gordo e levou-o em seus braços, de maneira ligeira, para baixo das escadas que davam acesso à estação. Ajeitou o cadáver cuidadosamente, como se desejasse escondê-lo. Ajoelhou-se comedida, cheirou o defunto e lambeu freneticamente o sangue morno que lhe escorria da orelha.

- Graças ao meu bom Deus te encontrei - disse com a saliva espumando em seus lábios.

O morto adiposo descansou tranquilamente em seu esconderijo. À meia-noite, quando o metrô completa sua jornada, a mulher e todos os outros faxineiros reuniram-se sob as escadas, resplandecentes de um vazio inimaginável há algumas horas. Nessa noite, os 
CASA, Vol.11 n.2, dezembro de 2013

cumprimentos entre eles foram esquecidos, pois os que chegavam assustavam-se logo com a imensidão do corpo que ali jazia.

- Vejam - disse um dos faxineiros, apontando a carcaça com uma mão e tapando a boca escancarada com a outra. - É muito grande. Parabéns, minha princesa!

- Não foi nada. Esse caiu do céu - observou a mulher, demonstrando modéstia.

Todos, então, retiraram as facas que guardavam numa discreta bainha pendurada na cintura. Despiram o morto, rasgando suas encardidas roupas, e, logo em seguida, começaram a retalhar-lhe a imensa quantidade de gordura amarelecida. Reuniram-se, depois, em círculo. Espetaram a carne nas pontas afiadas das vassouras, riram bastante, e assaram-na numa fogueira improvisada. 